DOI: https://doi.org/10.15407/preislamic2021.02.139

UDC $94(32)$

\title{
ANCIENT EGYPTIAN DENOTATIONS OF OBELISKS
}

\author{
A. A. Spartak \\ $\mathrm{PhD}$ (History) \\ Belarusian State University of Culture and Arts, \\ 17, Rabkorovskaya Str., Minsk, 220008, Belarus \\ spartakala@gmail.com
}

The article is devoted to the study of the ancient Egyptian denotations of obelisks. In Egyptian language, obelisks were denoted by the word txn. The etymology of this word is unknown. Apparently, the Egyptian word txn was associated with the physical characteristic of the named object (in the categories of the worldview of modern people) - with its luminosity (in the categories of the worldview of the ancient Egyptians). In different historical periods of the development of the ancient Egyptian state and depending on the stage of development of the Egyptian language, the obelisks had different designations. In the Amarna period, the ancient Egyptians used to denotation the obelisk the word bnbn. In all probability, it was associated with the religious reform of Akhenaten and an attempt to limit the influence of the Theban priesthood, distance from the Theban cult of Amun. Since obelisks were an ancient attribute of the institution of royal power, confirmation of the direct origin of the king from the sun god, Akhenaten had to use them in his ritual service. However, it was unacceptable to emphasize the connection of the obelisk with Amun, and the ancient Egyptians used the word bnbn to designate it. Since the ancient Egyptian perceived these objects as identical - as symbols of light and creation, the connection between them was obvious. Since the New Kingdom period, the hieroglyph "obelisk" has been used as a consonant component $(m+n)$ of the words mnw ("monument"), I mn ("Amun"), jmn ("hide"). Here, according to the author, it is more correct to resort to the interpretation of such an innovation through the changed worldview categories of the Egyptians of the New Kingdom, and, accordingly, the linguistic categories. The semantic field of the word "obelisk" in this period contained the words mnw - "monument" and I mn - "Amun", in both concepts the same hieroglyph mn was used which is a consonant component. The words formed from this hieroglyph expressed the idea of something both divine and firmly established, founded, fortified: for example, the verbal form $\mathrm{mn}$ - "to be strong, firm, strong, stay, be established". The obelisk had similar properties. Therefore, the characterization of $\mathrm{mn}$ should be understood as a characteristic of both the monuments themselves, and those periods of the history of Ancient Egypt when the obelisks were erected - periods of the firmly established world order of Maat, prosperity, stability.

Keywords: Ancient Egypt, obelisk, institution of royal power, Egyptian language

\section{A. A. Cnapmaк}

\section{СТАРАЖЫТНАЕГІПЕЦКІЯ ПАЗНАЧЭННІ АБЕЛІСКАЎ}

Класічны старажытнаегіпецкі абеліск уяўляе сабой каменную чатырохгранную калону, якая звужаецца наверсе і завяршаецца пірамідальным навершам, часцяком пакрытым золатам або электрумам ${ }^{1}$.

${ }^{1}$ Dam [TLA, lemma-no. 182710] - мінерал, разнавіднасць самароднага золата, сплаў срэбра i золата, у лацінскіх тэкстах “белае золата”; слова паходзіць ад грэчаскага үүлдєкроv / élektron, якое

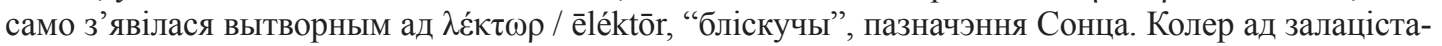
жоўтага да светла-жоўтага з металічным бляскам. 
На сённяшні дзень вядома каля 70 арыгінальных абеліскаў, і незлічоная колькасць копій. Абеліскі цароў: Тэці, Ініятэфа VII Нубхеперра, Сенусерта I, Тутмаса I, Хатшэпсут, Тутмаса III, Аменхатэпа II, Тутмаса III/Тутмаса IV, Сеці I, Сеці I/Рамзэса II, Рамзэса II, Мернептаха, Сеці II, Рамзэса IV, Псаммеціха II, Апрыя, Амасіса, Нектанэба II, Пталемея VIII Эвергета II; а таксама абеліскі, зробленныя па загаду рымскіх імператараў (Даміцыяна, Адрыяна), імітацыі, а часам і проста копіі егіпецкіх.

Слова “абеліск” мае грэчаскае паходжанне і ўпершыню фіксуецца ў V ст. да н. э.

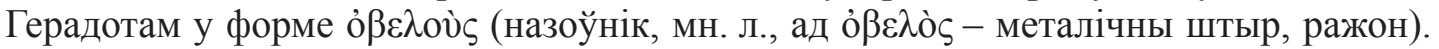
У гэтай жа форме слова было выкарастана амаль праз пяць стагоддзяў Іосіфам Фла-

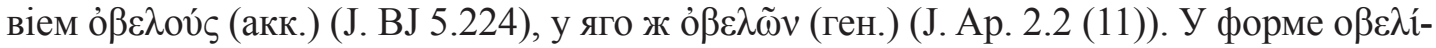

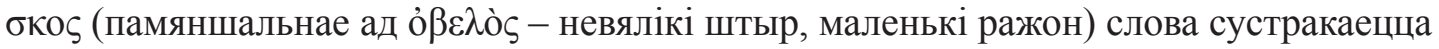
ў працах Страбона (Strabo, 17.1), Дыянісія Галікарнаскага (D.H. 5.46), Дыядора Ciцылійскага (Diod., I.46, 57, 59; II.11).

Традыцыйна лічыцца, што егіпецкае \t txn - “абеліск” (Gardiner’s Sign List (GSL) O25), паходзіць ад егіпецкага $\sqrt{\Omega}$ wbn - “свяціць; уздымацца (сонцу)” [TLA, lemma-no. 45050] (адсюль bnbn.t - пірамідыён [TLA, lemma-no. 55800]) і абазначае сонечны прамень [Budge 1926, 14-25; Nicholson, Shaw 2002, 208]. Магчыма, традыцыя разумення абеліска як сонечнага промня ідзе ад антычных аўтараў: Плінія Старэйшага і Аміяна Марцэліна, якія паспрабавалі перадаць старажытнаегіпецкі сэнс помнікаў праз лацінскую мову. Пліній Старэйшы ў сваёй "Натуральнай гісторыі" ўжыў слова trabs (лац. “бэлька, бервяно, кроква”, а таксама, “прамень” [A Latin Dictionary 1879, 1882]) у адносінах да абеліскаў: Trabes ex ео [Syenite lapide] fecere reges quodam certamine, obeliscos vocantes Solis numini sacratos, radiorum eius argumentum in effigie est - "Помнікі з яго [сіеніцкага камня] рабілі цары [у ходзе] нейкага спаборніцтва, называя абеліскамі, прысвечаныя боскай сіле Сонца, промні іх - гэта аповед у скульптуры" (Plin., Nat. Plin. 36, 8, 14, § 64 sq.). Аміян Марцелін каб падкрэсліць сувязь абеліскаў з культам Сонца выкарыстаў у адносінах да помніка слова radius: utque radium imitetur - "які імітуе прамень сонца" (Amm., 17. 4. 7).

У сярэднеегіпецкай мове сонечныя прамяні пазначаліся словам тор stw.t [TLA, lemma-no. 147910]. Слова з'яўлялася вытворным ад іерагліфічнага знака -कбo sti (GSL F29) - скура каровы, якую пракалолі стралой; з'яўляючыся ідэаграмай альбо дэтэрмінатывам, знак/слова былі семантычна звязаныя 3 дзеяслоўнай формай “калоць, праколваць” [Gardiner 1957, 464]. Відавочна, што ў егіпецкай мове фанетычнае напісанне txn не тоесна ні слову wbn (ці то $b n b n$ ), ні слову stw.t.

Выява, падобная да абеліску, у якасці складовай часткі слова ўпершыню фіксуецца ў перыяд праўлення IV дынастыі. У надпісах усходніх грабніц Плато Гізы, якія адносяцца да піраміды Хуфу, падобны да абеліску іерагліфічны (ці ідэаграфічны) знак размешчаны паміж знакамі mAt (“граніт") [TLA, lemma-no. 67580] i Abw (Асуан, ці Элефантына) [TLA, lemma-no. 81]. Паколькі слова з дэтэрмінатывам “абеліск” сустракаецца сярод пераліку пахавальнага інвентару [Lepsius 1904, Tafelwerke, Bd. III, Abth. II, Bl. 22], дадзены прадмет, хутчэй за ўсё, адносіўся да элементаў памінальнага культу. У гэтай жа грабніцы мы можам пабачыць выяву абеліску як асобнага прадмета. Абеліск намаляваны белым колерам (колерам сонечнага святла) (мал. 1).

Пазней, іерогліф [ сустракаецца ў тытулах жрацоў у назвах салярных храмаў V дынастыі цароў Сахура, Нэферыркара I, Нэферэфра (Ранеферэфа), Hiусера i 
Менкаўхора (Палермскі камень, таблічкі з храма Усеркафа, надпісы на сценах мастаб прыватных асоб і інш.) [Kaiser 1956, Abb. 1]. У гэтых надпісах ён абазначае як элемент, які стаіць асобна - “абеліск”, так і абеліск, усталяваны на іерогліфе "мастаба". Да перыяду кіравання VI дынастыі адносіцца першы фанетычны запіс егіпецкага слова "абеліск" - у надпісу Сабні, загадчыка Асуанскім раёнам, надпіс быў зроблены ў час кіравання Пепі II. Ягоны тэкст сведчыць пра тое, што абеліскі вырабляліся ў Асуане, у надпісу фігуруе не адзін абеліск, а пара - txn.wy (падв. лік).

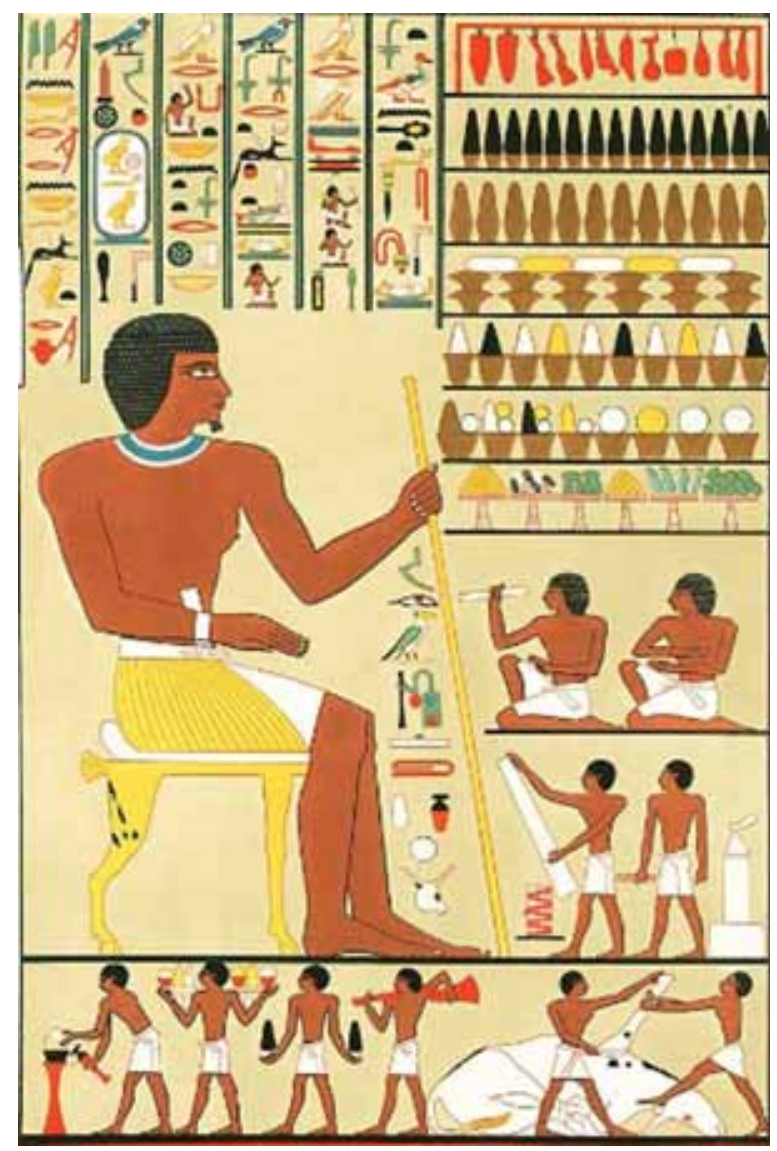

Мал. 1. Найстаражытнейшая выява абеліску. Надпісы ўсходніх грабніц Плато Гіза, якія адносяцца да піраміды Хуфу (па: [Lepsius 1904, Tafelwerke, Bd. III, Abth. II, Bl. 22])

У Тэкстах пірамідаў Пепі I таксама ёсць згадкі абеліскаў. Версія перакладу, прапанаваная К. Зётэ, гучыць як “...я - той, хто належыць двум абеліскам Ра, якія знаходзяцца на зямлі, і я - той, хто належыць Сфінксам Ра, якія знаходзяцца на нябёсах" [Sethe 1910, II, 157 (Sp. 515, § 1178)]. Верагодна, тут быy̆ дадзены не дакладны пераклад. Выйшла блытаніна словаў Ssp (“выява, статуя, сфінкс") [Gardiner 1957, 595] i sSp (“бліскучы прадмет”) [TLA, lemma-no. 854743]. Англамоўная версія перакладу выглядае так: “Пепі, той, які належыць двум абеліскам Сонца, якія належаць зямлі, Пепі - гэта той, хто належыць двум асляпляльным Сонца, якія належаць небу". Такі ж пераклад прапануе Тэзаўрус егіпецкай мовы:

$\S$ 1178a. (Рpy)|pw jr.y txn.w(j) n(.j).wy raw jr(.j).wy tA - "Пепі - гэта той, хто належыць да двух абеліскаў Ра, якія належаць зямлі”. 
§ 1178b. (Ppy)|pw jr.j sSp.wy [P/C ant/W $3=392]$ n(.j).wy raw jr(.j).w p.t - "Пепі той, хто належыць да двух светльх Ра, якія належаць нябёсам" [TLA, Pyramide Pepi I., PT 515].

У 2014 г. была прапанаваная расейская версія перакладу Ц. Шмакава:

1178a. NN pw jrjj txnwjj nwjj rajrwjj tA

NN pw txnwjj nw rajrwjj tA

NN pw jrj t\{n\}xnwjj nw rajrwjj tA

1178b. NN pw jrj s.Spwjj nwjj rajrw/jrwjj pt

NN pw jr.f s.Spwjj nwjj rajrwjj pt

"Пепи - направляющийся к двум обелискам Солнца земным. Пепи - направляющийся к двум светлылм/ослепительным Солнца небесным” [Шмаков 2014].

Верагодна, словы txnwjj и sSpwjj, якія з'яўляюцца ў сказе дапаўненнямі, сінанімічны паміж сабой. Яны ўваходзяць у адное і тое ж семантычнае поле і пазначаюць адны і тыя ж прадметы, якія пры розных абставінах праяўляюць розныя ўласцівасці. Такім чынам, зыходзячы з дадзенага фрагменту, можна казаць аб тым, што:

1. Абеліскі мелі дваістую прыроду, яны былі як элементамі свету прафаннага (зямнога), так і элементамі свету сакральнага (нябёснага).

2. Абеліскі мелі вызначаную i, хутчэй за ўсё, значную характарыстыку - святланоснасць.

Нямецкі егіптолаг К. Марцін выказаў здагадку, што tхn - “паток святла з нябёсаў на зямлю або ў процілеглым кірунку - ад чалавечай ахвяры да нябёснага боства. Звыклы сэнс $t$-прэфікса падкрэсліваў пастаянную працягласць працэсу” [Martin 1977, 36-39].

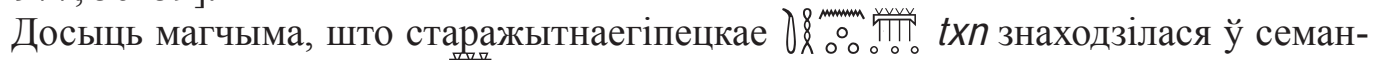
тычнай блізкасці са словам боб tHn (нейкае сыпкае рэчыва, якое мае яркі колер (“магчыма”, “шафран”) [TLA, lemma-no. 176570], якое выкарыстоўвалася як дзеяслоўная форма, “выказвала ідэю асвятлення, свячэння, ззяння, весялосці, радасці" [Chabas 1872,43$]$. Як вядома, шафран у стоўчаным выглядзе дадаваўся ў будаўнічыя матэрыялы, i, верагодна, надаваў нейкі залаты бляск альбо адценне матэрыялу: «як і словы “шкло” і “крышталь”, група tHn нясе ў сабе ідэю празрыстасці, бляску, выпраменьвання». “Сонца ўздымаецца; храмы выпраменьваюць tHn” [Chabas 1872, 43]; THn - “бляск” [TLA, lemma-no. 176590]. Ёсць усе падставы меркаваць, што да пачатку вытворчасці абеліскаў егіпцяне ўжо валодалі тэхнікай вытворчасці шкла. Адпаведна, яны цалкам маглі суадносіць уласцівасці кварцытавага абеліска і ўласна шкла. У Старажытным царстве слова вядома ў форме THn “бліскучы, яркі” [TLA, lemma-no. 176570] альбо THn.t "фаянс, шкло” [TLA, lemma-no. 176620]. Магчыма, tHn - гэта не стоўчаны шафран, а часцінкі кварцу, пяску. Але ж для канчатковага вызначэння сутнасці пазначэння абеліскаў праз $t x n$ у егіпецкай мове патрэбна вызначэнне ўсіх уласцівасцей чырвонага (ружовага) граніту пры яго выкарыстанні ў якасці аб’екта культу ці як ахвяры / паднашэння.

Цікава, што чырвоны або ружовы граніт, вядомы ў перыяд антычнасці як сіеніт (па назве г. Сіена (стар.-егіп. swnt.t, Асуан), згодна Плінію Старэйшаму, грэкамі зваўся

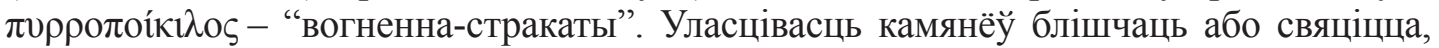
адзначанае антычным аўтарам, цалкам магла суадносіцца старажытнымі егіпцянамі 3 уласцівасцямі шкла, кварцу. Асабліва, калі абеліскі разглядаліся як materia magica ${ }^{2}$.

\footnotetext{
${ }^{2}$ Матэрыяльныя прадметы, якія валодалі звышнатуральнымі якасцямі.
} 
У тэкстах надпісаў на абелісках таксама адзначаецца, што абеліскі выконвалі функцыю святла, што яны асвятлялі прастору храма і тэрыторыю вакол храма (табл. 1). Ідэя асвятлення (святла) як аднаго са складовых элементаў прызначэння абеліскаў была выказана Фр.-Ж. Шаба ў 1868 годзе: “3 аднаго боку, яны ўвасаблялі прамяні сонца. Цалкам пазалочаныя абеліскі сапраўды павінны былі распаўсюджваць яркія блікі, якія адлюстроўваюць гарачае сонца егіпецкага неба" [Chabas 1868, 11]. На абеліску VII (згодна К. Кітчэну) Рамзеса II з Танісу (першапачаткова - 3 ПерРамзесу) ёсць надпіс, у якім цар параўноўваецца з Атумам, які валодае ўласцівасцю крыніцы святла: "Рамзэс, цар улюбёны, падобны да Атуму, які асвячае Абедзьве зямлі, калі з'яўляецца як Ра-Харахці” (KRI II, 245 (H, obelisk VII, NF, 417:1)).

Табліца 1. Сведчанні ў надпісах на абелісках аб іх функцыі светланоснасці

\begin{tabular}{|c|c|c|c|}
\hline Цар & Абеліскі & Транслітэрацыя & Пераклад \\
\hline Хатшэпсут & $\begin{array}{l}\text { Карнакскі } \\
\text { абеліск }\end{array}$ & $\begin{array}{l}\text { saHa n.f txnwy wrwy r sbA } \\
\text { Sps I mn wr Sfyt bAk m Damw aA } \\
\text { wrt sHd n t3wy mi I Tn-Ra } \\
\text { [Urk. IV, } 357 \text { (A. 1)] }\end{array}$ & $\begin{array}{l}\text { “Усталявана для яго (Амона) два } \\
\text { вялікіх абеліска перад брамай вяліка- } \\
\text { га Амона, якія зверху пакрытыя цу- } \\
\text { доўным золатам, каб асвятлялі яны } \\
\text { (абеліскі) абедзьве зямлі як сонца" }\end{array}$ \\
\hline Хатшэпсут & $\begin{array}{l}\text { База паў- } \\
\text { ночнага } \\
\text { абеліска } 3 \\
\text { Карнака }\end{array}$ & $\begin{array}{l}\text { bahi n stwt sn tAwy wbn iTn- } \\
\text { ra imytw.ny mi xa.f m Axt nt pt } \\
\text { [Lepsius 1900, Tafelwerke, } \\
\text { Bd. V, Abth. III. Bl. } 24,7.14- \\
7.16] \text {. }\end{array}$ & $\begin{array}{l}\text { “Запаўняюць прамяні іх (аб- } \\
\text { еліскаў) абедзьве зямлі, калі свеціць } \\
\text { Атум-Ра паміж імі, падобна таму, як } \\
\text { з'яўляецца ён, ззяючы над гарызон- } \\
\text { там” }\end{array}$ \\
\hline Тутмас III/IV & $\begin{array}{l}\text { Латэранскі } \\
\text { абеліск }\end{array}$ & $\begin{array}{l}\text { sA Ra [Dxwty-xams-xaw] } \\
\text { sahan.f sw m Ipt-swtir bnbnt.f } \\
\text { m Damw Hd n nfrw.f WAst } \\
\text { (Рым, Латэранская плошча, } \\
\text { паўднёвы бок, правы стаў- } \\
\text { бец) }\end{array}$ & $\begin{array}{l}\text { “Сын Ра, Тутмас, увянчаны вян- } \\
\text { камі, загадаў ён усталяваць яго (абе- } \\
\text { ліск) ў Карнаку, зрабіўшы пірамідыён } \\
\text { яго залатым, каб асвячала прыгажосць } \\
\text { ягоная Фівы” }\end{array}$ \\
\hline $\begin{array}{l}\text { усталяваны } \\
\text { Рамзэсам II } \\
\text { дзеля Сеці I }\end{array}$ & $\begin{array}{l}\text { Абеліск } \\
\text { Фламіныа }\end{array}$ & $\begin{array}{l}\text { Nsw-bit [mn-mAt-Ra] Mh } \\
\text { I pt-swt m thnw hr wbn stwt } \\
\text { pr-ra(абеліск Фламініа, Рым, } \\
\text { заходні бок, цэнтр. стаўбец) }\end{array}$ & $\begin{array}{l}\text { “Цар Верхняга і Ніжняга Егіпту - } \\
\text { Сеці, той, хто напоўніў Іуну абеліс- } \\
\text { камі, каб асвятлялі сонечныя прамяні } \\
\text { дом Ра" }\end{array}$ \\
\hline
\end{tabular}

Такім чынам, егіпецкае txn адлюстроўвала ідэю святла і характарызавала дадзеныя каменныя помнікі як тыя, якія выпраменьваюць святло, ззяюць, блішчаць. Гэта паток святла, дынамічны і бесперапынны. Відавочна, слова txn звязана не з пазначэннем сонечнага праменя, а 3 пазначэннем ўласцівасці самога помніка - яго святланоснасцю (першапачаткова, уласцівасцю самога камня (ягонай складаючай часткі - кварцу), пасля, магчыма, і пазалочанага/ 3 электрума наверша). Г. зн. 3 тым, як успрымалі старажытныя егіпцяне гэтыя помнікі, калі глядзелі на іх, - камень, які свеціцца. Бог Ра, цар і абеліскі з'яўляліся субстанцыямі, якія валодалі якасцямі крыніцы (выпраменьвальніка) святла, г. зн. сакральнымі якасцямі.

У тэкстах на саміх абелісках досыць часта ўжываецца канструкцыя ir.n.f m mnw.f n it.f “ён усталяваў помнік (абеліск) ягоны для айца ягонага”. Адсюль вынікае, што слова txn у егіпецкай мове з'яўлялася нейкай разнавіднасцю mnw. А. Эрман і Г. Грапаў у сваім слоўніку прыводзяць для іерогліфа “абеліск” транслітэрацыю mnw, спасылаючыся на тое, што сэнс вызначаецца з пазнейшых надпісаў, і перакладаюць як 
“абеліск” [TLA, lemma-no. 70440, Wb. II, 71.9-10]. Таксама ў слоўніку адзначаецца, што слова паходзіць ад абазначэння пахавальнага інвентара, які меў надпісы. У больш агульным значэнні mnw ўжывалася для абазначэння помнікаў, надмагілляў, статуй і т. д. [Wb. II, 70-71].

Пачынаючы з Амарнского перыяду, мы назіраем замену ўжывання txn на bnbn [TLA, lemma-no. 55720, Amarna-Periode, Gebel Silsile, Stele Amenophis IV. (line [5])]. Гэта, на наш погляд, было звязана з рэлігійнай рэформай Эхнатона і спробай абмежавання ўплыву фіванскага жрэцтва, дыстанцыявання ад фіванскага культу Амона. Верагодна, да гэтага перыяду абеліск ужо трывала асацыяваўся з культам Амона. Аднак, улічваючы тое, што абеліск быў старажытным атрыбутам інстытута царскай улады, пацверджаннем непасрэднага паходжання цара ад бога Сонца, абеліск не мог не выкарыстоўвацца Эхнатонам у яго рытуальным служэнні. Але паколькі падкрэсліваць сувязь абеліска з Амонам было недапушчальна, для абазначэння абеліска выкарыстоўвалі слова bnbn. Паколькі аб'екты ўспрымаліся як тоесныя як сімвалы святла і крэацыі, сувязь паміж імі і іх тоеснасць былі відавочныя.

Пачынаючы 3 перыяду Новага царства, іерогліф [ выкарыстоўваецца як кансанантная складаючая $(m+n)$ слоў mnw (“помнік”), I mn (“Амон”), jmn (“хаваць”) [LÄ 1982, IV, 543; Martin 1977, 134-136]. У тытулах жрацоў яно пачынае замяняць імя Амона, што некаторымі егіптолагамі трактуецца як доказ сувязі егіпецкага іерагліфічнага знака 3 характарыстыкай бога Амона “схаваны”. Аднак у надпісах на абелісках змены ў фанетыцы слова не прасочваюцца. Улічваючы тое, што ў дадзеным выпадку іерогліф з'яўляецца ўжо не лексічнай адзінкай мовы, а фанемай - часткай лексічнай адзінкі, - рабіць высновы аб яе значэнні не зусім карэктна. Тут, як нам падаецца, трэба звярнуцца да трактоўкі падобнага новаўвядзення праз тыя змены, якія адбыліся ў светапоглядзе егіпцян перыяду Новага царства, а, адпаведна, і змены ў моўных катэгорыях. У кантэксце ўжывання слова “абеліск” у дадзены перыяд прысутнічалі словы mnw - “помнік” і Imn - “Амон”, у абодвух паняццях выкарыстоўваўся адзін і той жа іерогліф ] mn, які з'яўляецца кансанантнай складаючай. Словы, утвораныя ад гэтага іерогліфа, пазначалі ідэю чагосьці адначасова і боскага i трывала ўсталяванага, заснаванага, ўмацаванага: напрыклад, дзеяслоўная форма mn - “быць трывалым, цвёрдым, моцным, заставацца, быць усталяваным”. Гэтымі характарыстыкамі валодаў абеліск.

Абеліскі выказвалі ідэю святла і крэацыі на працягу пэўнага перыяду ў гісторыі Старажытнага Егіпта. Верагодна, у эпоху Трэцяга пераходнага перыяду (праўленне XXII лівійскай дынастыі) ідэя святла была не такая актуальная, як раней, і пераважнае значэнне мела менавіта разуменне абеліскаў як сімвалаў крэацыі, а таксама трывала ўстаноўленых правіл светабудоўлі. I абазначэнне mn варта разумець не як абазначэнне ўласцівасці Амона (быць схаваным), а як характарыстыку і саміх помнікаў, і тых перыядаў гісторыі Старажытнага Егіпту, калі абеліскі ўсталёўваліся, перыядаў трывала ўстаноўленай светабудоўлі Маат, дастатку, стабільнасці.

\section{СКАРАЧЭННІ}

KRI - Kitchen K. A. (1968-1989), Ramesside inscriptions: historical and biographical, Vol. 1-8, Monumenta Hannah Sheen dedicate, 4, Wiley-Blackwell, Oxford.

LÄ - Helck W. and Otto E. (eds) (1975-1986), Lexikon der Ägyptologie, Bd. I-VI, Otto Harrassowitz, Wiesbaden. 
TLA - Thesaurus Linguae Aegyptiae, available at: http://aaew.bbaw.de/tla, (accessed 29.11.2020).

Urk. IV - Sethe K. Urkunden der 18. Dynastie (1906-1909), Urkunden des aegyptischen Altertums, Bd. IV, J. C. Hinrich'sche Buchhandlung, Leipzig.

Wb. - Grapow H. and Erman A. (eds) (1955), Wörterbuch der aegyptischen Sprache, Bd. I-V, Akademie Verlag, Berlin.

\section{REFERENCE}

A Latin Dictionary (1879), Founded on Andrews'edition of Freund's Latin Dictionary. Revised, enlarged, and in great part rewritten by Charlton T. Lewis, Ph.D. and Charles Short, LL.D, Clarendon Press, Oxford.

Budge E. A. W. (1926), Cleopatra's needles and other Egyptian obelisks: descriptions of all the important inscribed obelisks, with hieroglyphic texts, translations, etc., Religious Tract Soc., London.

Chabas F. J. (1868), Traduction complète des inscriptions hiéroglyphiques de l'obélisque de Louqsor, place de la Concorde à Paris, Maisonneuve, Paris.

Chabas F. J. (1872), Études sur l'antiquité historique: d'après les sources égyptiennes et les monuments réputés préhistoriques, Maisonneuve, Paris.

Gardiner A. H. (1957), Egyptian Grammar. Being an Introduction to the Study of Hieroglyphs, $3^{\text {rd }}$ Edition, Griffith Institute \& Ashmolean Museum, Oxford.

Kaiser W. (1956), "Zu den Sonnenheiligtümern der 5. Dynastie", in Mitteilungen des Deutschen Archäologischen Instituts, Abteilung Kairo, Bd. 14, Harrassowitz Verlag, Wiesbaden, pp. 104-16.

Lepsius K. R. (1849-1859), Denkmaeler aus Aegypten und Aephiopien, Universitätsund Landesbibliothek Sachsen-Anhalt, available at: http://edoc3.bibliothek.uni-halle.de/ lepsius (accessed 29.11.2020).

Martin K. (1977), Ein Garantsymbol des Lebens. Untersuchung zu Ursprung und Geschichte der altägyptischen Obelisken bis zum Ende des Neuen Reiches, Hildesheimer Ägyptologische Beiträge, 3, XVII, Gerstenberg Verlag, Hildesheim.

Nicholson P. and Shaw I. (eds) (2002), The British Museum Dictionary of Ancient Egypt, British Museum Press, London.

Sethe K. (1910), Die altägyptischen Pyramidentexte nach den Papierabdrucken und Photographien des Berliner Museums, Bd. II: Spruch 469-714 (Pyr. 906-2217), J. C. Hinrichsche Buchhandlung, Leipzig.

Shmakov T. T. (2014), Drevneyegipetskiye teksty piramid (rabochaya versiya), available at: https://www.academia.edu/7712009_(accessed 29.11.2020). (In Russian).

\section{А. А. СПартаК
СТАРАЖЫТНАЕГІПЕЦКІЯ ПАЗНАЧЭННІ АБЕЛІСКАЎ}

Артыкул прысвечаны вывучэнню старажытнаегіпецкіх пазначэнняў абеліскаў. У егіпецкай мове абеліскі пазначаліся словам txn. Этымалогія гэтага слова невядомая. Верагодна, егіпецкае слова txn было звязана з фізічнай характарыстыкай аб'екта (у катэгорыях светапогляду сучасных людзей) - 3 яго святланоснасцю (у катэгорыях светапогляду старажытных егіпцян). У розныя гістарычныя перыяды развіцця старажытнаегіпецкай дзяржавы і ў залежнасці ад стадыі развіцця егіпецкай мовы абеліскі мелі розныя пазначэнне. У Амарнскі перыяд старажытныя егіпцяне выкарыстоўвалі для абазначэння абеліска слова bnbn. Biдавочна, гэта было звязана з рэлігійнай рэформай Эхнатона і спробай абмежаваць уплыў 


\section{А. А. Спартак}

фіванскага жрэцтва, дыстанцыявацца ад фіванскага культу Амона. Паколькі абеліскі былі старажытным атрыбутам інстытута царскай улады, пацверджаннем прамога паходжання цара ад бога Сонца, Эхнатону даводзілася выкарыстоўваць іх у сваім рытуальным служэнні. Аднак было непрымальна падкрэсліваць сувязь абеліска з Амонам, $і$ для пазначэння абеліска выкарыстоўвалася слова bnbn. Паколькі аб'екты ўспрымаліся як тоесныя - як сімвалы святла і крэацыі, сувязь паміж імі была відавочная. 3 часоў Новага царства іерогліф “абеліск" выкарыстоўваўся як кансанантная складаючая $(m+n)$ слоў $m n w$ (“помнік”), I mn (“Амон”), jmn (“хаваць”). Тут, на думку аўтара, правільней было б звярнуцца да інтэрпрэтацыі такога новаўвядзенні праз змяненні ў светапоглядзея егіпцян Новага царства, i, адпаведна, праз змяненні у лінгвістычных катэгорыях. Семантычнае поле слова “абеліск” у гэты перыяд утрымлівала словы mnw - “помнік” i I mn - “Амон”, у абодвух паняццях выкарыстоўваўся адзін і той жа іерогліф mn, які з'яўляецца кансанантнай складаючай. Словы, утвораныя ад гэтага іерогліфа, выказвалі ідэю чагосьці адначасова чароўнага і цвёрда ўсталяванага, заснаванага, умацаванага: напрыклад, дзеяслоўная форма $\mathrm{mn}$ - “быць моцным, непахісным; заставацца; быць зацверджаным”. Абеліск меў падобныя ўласцівасці. Такім чынам, характарыстыку mn варта разумець як характарыстыку саміх помнікаў, так і тых перыядаў гісторыі Старажытнага Егіпта, калі ўзводзіліся абеліскі - перыядаў трывала ўсталяванага сусветнага парадку Маат, дабрабыту, стабільнасці.

Ключавыя словы: Старажытны Егіпет, абеліск, інстытут царскай улады, егіпецкая мова

\section{A. O. Cnapmak}

\section{ДАВНЬОСГИПЕТСЬКІ ПОЗНАЧЕННЯ ОБЕЛІСКУ}

Стаття присвячена розгляду давньоєгипетських позначень обелісків. У єгипетській мові обеліски позначалися словом txn. Етимологія цього слова невідома. Можливо, єгипетське слово txn було пов'язано з фізичною характеристикою названого об'єкта (в категоріях світогляду сучасних людей) - 3 його світлоносності (в категоріях світогляду давніх єгиптян). У різні історичні періоди розвитку давньоєгипетської держави і в залежності від стадії розвитку єгипетської мови обеліски набували різних позначень. В Амарнський період єгиптяни використовували для позначення обеліска слово bnbn. По всій видимості, це було пов'язано 3 релігійною реформою Ехнатона і його спробою обмежити вплив фіванського жрецтва, дистанціюватися від фіванського культу Амона. Оскільки обеліски були давнім атрибутом інституту царської влади, підтвердженням прямого походження царя від бога сонця, Ехнатону доводилося використовувати їх у своєму ритуальному служінні. Однак було неприйнятним підкреслювати зв'язок обеліска 3 Амоном і тому для позначення обеліска використовувалося слово bnbn. Оскільки об'єкти сприймалися як ідентичні - як символи світла та творіння, зв'язок між ними був очевидним. 3 часів Нового царства ієрогліф “обеліск" використовувався як консонантний компонент $(m+n)$ у словах mnw (“пам'ятник"), I mn (“Амон”), jmn (“"приховувати”). Тут, на думку автора, правильніше вдатися до інтерпретації такого нововведення через зміни світоглядних категорій єгиптян Нового царства, i, відповідно, лінгвістичних категорій. Семантичне поле слова "обеліск” в цей період містило слова mnw - “пам'ятник” i Imn - “Амон”, в обох поняттях використовувався один і той же ієрогліф mn, який є консонантним компонентом. Слова, утворені з цього ієрогліфа, висловлювали ідею чогось одночасно божественного і твердо встановленого, заснованого, укріпленого: наприклад, дісслівна форма $\mathrm{mn}$ - “бути сильним, непохитним; залишатися; бути затвердженим". Обеліск мав схожі властивості. Отже, характеристику $\mathrm{mn}$ слід розуміти як характеристику як самих пам'ятників, так і тих періодів історії Стародавнього Єгипту, коли зводилися обеліски - періодів міцно встановленого світового порядку Маат, процвітання, стабільності.

Ключові слова: Стародавній Єгипет, обеліск, інститут царської влади, єгипетська мова 